\title{
Precipitation and synoptic regime in two extreme years 2009 and 2010 at Dome C, Antarctica - implications for ice core interpretation
}

\author{
Elisabeth Schlosser ${ }^{1,2}$, Barbara Stenni ${ }^{3}$, Mauro Valt ${ }^{4}$, Anselmo Cagnati $^{4}$, Jordan G. Powers ${ }^{5}$, Kevin W. Manning ${ }^{5}$, \\ Marilyn Raphael $^{6}$, and Michael G. Duda ${ }^{5}$ \\ ${ }^{1}$ Inst. of Atmospheric and Cryospheric Sciences, University of Innsbruck, Innsbruck, Austria \\ ${ }^{2}$ Austrian Polar Research Institute, Vienna, Austria \\ ${ }^{3}$ Department of Environmental Sciences, Informatics and Statistics, University of Venice, Venice, Italy \\ ${ }^{4}$ ARPA Center of Avalanches, Agenzia Regionale per la Prevenzione e Protenzione Ambientale de Veneto, Italy \\ ${ }^{5}$ National Center for Atmospheric Research, Boulder, CO, USA \\ ${ }^{6}$ Department of Geography, University of California, Los Angeles, California, USA
}

Correspondence to: E. Schlosser (elisabeth.schlosser@uibk.ac.at)

Received: 19 September 2015 - Published in Atmos. Chem. Phys. Discuss.: 4 November 2015

Revised: 23 March 2016 - Accepted: 6 April 2016 - Published: 18 April 2016

\begin{abstract}
At the East Antarctic deep ice core drilling site Dome $\mathrm{C}$, daily precipitation measurements were initiated in 2006 and are being continued until today. The amounts and stable isotope ratios of the precipitation samples as well as crystal types are determined. Within the measuring period, the two years 2009 and 2010 showed striking contrasting temperature and precipitation anomalies, particularly in the winter seasons. The reasons for these anomalies are analysed using data from the mesoscale atmospheric model WRF (Weather Research and Forecasting Model) run under the Antarctic Mesoscale Prediction System (AMPS). 2009 was relatively warm and moist due to frequent warm air intrusions connected to amplification of Rossby waves in the circumpolar westerlies, whereas the winter of 2010 was extremely dry and cold. It is shown that while in 2010 a strong zonal atmospheric flow was dominant, in 2009 an enhanced meridional flow prevailed, which increased the meridional transport of heat and moisture onto the East Antarctic plateau and led to a number of high-precipitation/warming events at Dome C. This was also evident in a positive (negative) SAM (Southern Annular Mode) index and a negative (positive) ZW3 (zonal wave number three) index during the winter months of 2010 (2009). Changes in the frequency or seasonality of such event-type precipitation can lead to a strong bias
\end{abstract}

in the air temperature derived from stable water isotopes in ice cores.

\section{Introduction}

Although Antarctic precipitation has been studied for approximately half a century (see e.g. Bromwich, 1988), a number of open questions remain. There are two key motivations for studying Antarctic precipitation. The first is that precipitation/snowfall is the most important positive component of the mass balance of Antarctica. This is receiving increasing attention in discussions of climate change since the mass balance response to global warming can considerably influence sea level change. A possible increase of precipitation in a future climate due to higher air temperatures and therefore increased saturation vapour pressure would mean storage of larger amounts of water in the Antarctic ice sheet, thus mitigating sea level rise (Church et al., 2013). So far, the expected increase in precipitation has not been found in the measurements (e.g. Monaghan et al., 2006). However, in one projection derived from a combination of various models and ice core data, Frieler et al. (2015) stated a possible increase in Antarctic accumulation on the continental scale of approximately $5 \% \mathrm{~K}^{-1}$. In some parts of Antarctica, higher 
accumulation would lead to increased ice flow and thus dynamical ice loss, which would reduce the total mass gain (Winkelmann et al., 2012; Harig and Simons, 2015). Thus, for modelling and calculation of the Antarctic mass balance, precipitation amounts and precipitation regimes have to be known as exactly as possible.

A second driver for studying Antarctic precipitation is that the ice of Antarctica is an unparalleled climate archive: ice cores up to 800000 years old yield crucial information about palaeotemperatures and the past constitution of the atmosphere (e.g. EPICA community members, 2004). To derive former air temperatures from ice cores, the stable-isotope ratios of water are used primarily. A linear spatial relationship has been found between mean annual stable isotope ratios in Antarctic precipitation and annual mean air temperature at the deposition site although the isotope ratios depend in a complex way on mass-dependent fractionation processes during moisture transport and precipitation formation (Dansgaard, 1964). This spatially derived linear relationship has been found not to hold temporally, however (Jouzel, 2014; Jouzel et al., 2003). Apart from air temperature, several other factors influence the stable isotope ratio, such as seasonality of precipitation, location of and conditions at the moisture sources and conditions along moisture transport paths (e.g. Noone et al., 1999; Schlosser, 1999; Jouzel et al., 2003; Sodemann and Stohl, 2009; Sodemann et al., 2008). Thus, for a correct interpretation of the ice core data a thorough understanding of the atmospheric processes responsible for the precipitation is needed, as it was the precipitation that ultimately formed the glacier ice investigated in the cores. In particular, information about precipitation mechanisms, moisture sources and transport paths, and atmospheric conditions at the final deposition site is required.

Measuring Antarctic precipitation is a challenge, not only due to the remoteness and extreme climate of the continent, but also due to difficulties in distinguishing between drifting/blowing snow and falling precipitation. The latter is due to the high wind speeds that typically accompany precipitation events in coastal areas. In the interior of the continent, while wind speeds are lower than at the coast, the threshold for drifting snow is often lower due to lower snow densities as well. Measurements are also complicated by the extremely small amounts of precipitation produced in the cold and dry air. Precipitation measurements with optical devices may hold some hope for improved data in the future, but these instruments are currently in the testing phase in Antarctica (Colwell, personal communication, 2015). In light of the lack of observations, atmospheric models have become increasingly useful tools to investigate Antarctic precipitation (Noone and Simmons, 1998; Noone and Simmons, 2002; Noone et al., 1999; Bromwich et al., 2004; Schlosser et al., 2008, 2010a, b).

This study focusses on the differences in the precipitation regime of two contrasting years within the short measuring period, motivated by the consequences different precipitation and/or flow regimes have on stable isotope interpretation. The present investigation concentrates on the years 2009 and 2010. These years were chosen because they showed striking contrasting temperature and precipitation anomalies, particularly in the winter seasons. Fogt (2010) reported that temperatures in the Antarctic were persistently above average in the mid-to-lower troposphere during the winter of 2009. The positive surface temperature anomalies were most marked in East Antarctica. In 2010, the picture was very different from 2009, with generally below-average temperatures on the East Antarctic plateau in winter and spring (Fogt, 2011).

\section{Study site}

Dome C $\left(75.106^{\circ} \mathrm{S}, 123.346^{\circ}\right.$ E, elevation $\left.3233 \mathrm{~m}\right)$ is one of the major domes on the East Antarctic ice sheet. Its mean annual temperature is $-54.5^{\circ} \mathrm{C}$, and the mean annual accumulation derived from ice cores amounts to $25 \mathrm{~mm}$ water equivalent (w.e.) $\mathrm{yr}^{-1}$. Several deep ice cores have been retrieved at Dome C, the first one in 1977/78, reaching a depth of $906 \mathrm{~m}$, corresponding to an age of approximately 32000 years. The thermally drilled core was retrieved during the International Antarctic Glaciological Project (Lorius et al., 1979).

The oldest ice to date has been obtained at Dome C through the European deep drilling project EPICA (European Project for Ice Coring in Antarctica). The drilling was completed in January 2006; at the base of the $2774.15 \mathrm{~m}$ long ice core the age of the ice was estimated to be 800000 years, thus covering eight glacial cycles (EPICA community members, 2004). To support the EPICA drilling operation, the FrenchItalian Antarctic wintering base Dome Concordia became operational in 2005.

\section{Previous work}

Precipitation conditions in the interior of Antarctica are very different from those in coastal areas. Whereas precipitation at the coast is usually caused by frontal systems of passing cyclones that form in the circumpolar trough (e.g. Simmonds et al., 2002), in the interior different precipitation mechanisms are at play. On the majority of days, only diamond dust, also called clear-sky precipitation, is observed. It forms due to radiative cooling in a nearly saturated air mass. Although diamond dust is predominant temporally, it does not necessarily account for the largest fraction of the total yearly precipitation. It has been shown that a few snowfall events per year can bring up to $50 \%$ of the total annual precipitation (Braaten, 2000; Reijmer and van den Broeke, 2003; Fujita and Abe, 2006; Schlosser et al., 2010a; Gorodetskaya et al., 2013). Those events are due to amplification of Rossby waves in the circumpolar westerlies, which increases the meridional transport of heat and moisture polewards. In extreme cases this can even mean a transport from the Atlantic 
sector across the continent to the Pacific side (Sinclair, 1981; Schlosser et al., 2010a, b. The relatively moist and warm air is orographically lifted over the ice sheet, followed by cloud formation and/or precipitation (Noone et al., 1999; Massom et al., 2004; Birnbaum et al., 2006; Schlosser et al., 2010a, b). Except for the study by Fujita and Abe (2006), all of these investigations were based on model and Automatic Weather Station (AWS) data, rather than daily precipitation measurements.

For a long time it was believed in ice core studies that precipitation represented in Antarctic ice cores is formed close to the upper boundary of the temperature inversion layer assuming that the largest moisture amounts are found where the air temperature is highest (Jouzel and Merlivat, 1984). This is a very simplified view that is, however, widely used in ice core studies. It assumes that there are basically no multiple temperature inversions and that humidity is only dependent on temperature through the Clausius-Clapeyron equation, which describes the temperature dependence of vapour pressure. This would mean that humidity and temperature inversions would always have a similar profile. However, more recent studies have shown that humidity inversions are parallel to the temperature inversion only in $50 \%$ of the cases, and often multiple humidity (and temperature) inversions occur (Nygard et al., 2013). In particular, the local cycle of sublimation and re-sublimation (deposition) is poorly known, but it is important for both mass balance and isotope fractionation studies.

At Dome Fuji, at an elevation of $3810 \mathrm{~m}$, the air can be so dry that, in spite of the advection of warm and moist air related to amplified Rossby waves, no precipitation is observed at the site. However, this synoptic situation can cause a strong warming in the lower boundary layer (particularly during blocking situations) due to a combination of warm air advection and removal of the temperature inversion layer by increased wind speed that induces mixing and cloud formation, which in turn increases downwelling longwave radiation (Enomoto et al., 1998; Hirasawa et al., 2000). Increased precipitation amounts can also be observed after a snowfall event when the warm air advection has ended, but increased levels of moisture prevail, which can lead to extraordinarily high amounts of diamond dust precipitation (Hirasawa et al., 2013). In West Antarctica, intrusions of warm, marine air can lead to increased cloudiness, precipitation and air temperature. A change in the frequency or intensity of such warm air intrusions could have a large effect on West Antarctic climate if the mean general circulation changed (Nicolas and Bromwich, 2011).

Moisture origin has been investigated in various studies using back-trajectory calculations employing different models and methods (Reijmer et al., 2002; Sodemann et al., 2008; Suzuki et al., 2008; Sodemann and Stohl, 2009; Scarcilli et al., 2010). In a recent study by Dittmann et al. (2016), who investigated precipitation and moisture sources at Dome $F$ for precipitation events in 2003, it was estimated that the origin

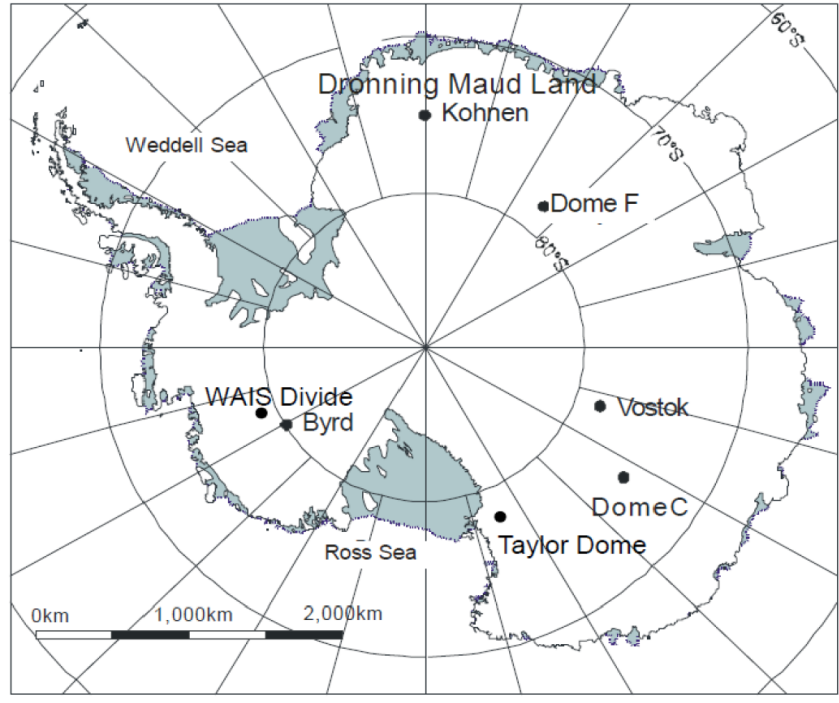

Figure 1. Map of Antarctica indicating Dome $\mathrm{C}$ and other important deep-drilling sites in Antarctica.

of the moisture was farther south (on average at $50^{\circ} \mathrm{S}$ and the transport occurred lower in the atmosphere) than previously assumed in ice core studies (Masson-Delmotte et al., 2008).

Dome $\mathrm{C}$ is a deep ice core drilling site. However, the measurements presented here are the first derived from fresh snow samples at this site. A similar study, if only for a period of approximately 1 year, was carried out by Fujita and Abe (2006) at Dome Fuji (see Fig. 1), another deep-drilling site in East Antarctica. They investigated daily precipitation data together with measurements of stable isotope ratios of the precipitation samples. Temporal variations of $\delta^{18} \mathrm{O}$ were highly correlated with air temperature. Half of the annual precipitation resulted from only 11 events (18 days), without showing any seasonality. The other half was due to diamond dust. Similar results were found in studies by Schlosser et al. (2010a), at Kohnen Station (see Fig. 1) and by Reijmer and Van den Broeke (2003), who used data from automatic weather stations in Dronning Maud Land. The precipitationweighted temperature was significantly higher than the mean annual surface temperature because the precipitation events were related to warm-air advection, which leads to a warm bias in the $\delta^{18} \mathrm{O}$ record.

\section{Data and methods}

\subsection{Precipitation}

Daily precipitation measurements were initiated at Dome C in 2006, and have, with some interruptions, been continued until today. Daily precipitation amounts are measured using a wooden platform set up at a distance of $800 \mathrm{~m}$ from the main station, at a height of $1 \mathrm{~m}$ above the snow surface to avoid contributions from low drifting snow. For the same rea- 
son, the platform is surrounded by a rail of approximately $8 \mathrm{~cm}$ height. The measurements include precipitation sampling and analysis of stable water isotopes $\left(\delta^{18} \mathrm{O}, \delta \mathrm{D}\right)$ of the samples. Additionally, the crystal structure of the precipitation is analysed in order to distinguish between diamond dust, snowfall, and drift snow. Diamond dust consists of extremely fine ice needles whereas synoptic snowfall shows various types of regular snow crystals, which tend to be broken in case of drifting and/or blowing snow. The snow crystal type depends on air temperature during formation in the cloud. Samples of mixed crystal types can also occur.

While errors of the precipitation measurements cannot be quantified, it is understood that they can exceed $100 \%$ given the extremely small precipitation amounts.

The Dome C precipitation series is the first and so far only multi-year combined precipitation-stable isotope series at an Antarctic deep ice core drilling site.

\subsection{AWS data}

The Antarctic Meteorological Research Center (AMRC) and Automatic Weather Station (AWS) Program are sister projects of the University of Wisconsin-Madison funded under the United States Antarctic Program (USAP) that focus on data for Antarctic research support, providing realtime and archived weather observations and satellite measurements and supporting a network of automatic weather stations across Antarctica.

The current AWS at Dome C was set up by the AMRC, in December 1995. The station measures the standard meteorological variables of air temperature, pressure, wind speed, wind direction, and humidity. Data can be obtained from http://amrc.ssec.wisc.edu. Note that an initial AWS (named Dome C) had been set up in 1985, however, at a distance of about $70 \mathrm{~km}$ from the current site. Thus, only data from the new station (Dome C II) are used in the present study.

\subsection{WRF model output from the AMPS archive}

In addition to the observations described above, this study uses numerical weather prediction (NWP) model output for analysis of the synoptic environments of the target years, of precipitation processes, and of events. The output is from forecasts of the Weather Research and Forecasting (WRF) Model (Skamarock et al., 2008) run under the Antarctic Mesoscale Prediction System (AMPS; Powers et al., 2003, 2012), a real-time NWP capability that supports the weather forecasting for the United States Antarctic Program (USAP). The (US) National Center for Atmospheric Research (NCAR) has run AMPS since 2000 to produce twicedaily forecasts covering Antarctica with model grids of varying resolutions. The AMPS WRF forecasts have been stored in the AMPS Archive and used extensively in studies (e.g. Monaghan et al., 2005; Schlosser et al., 2008; Seefeldt and Cassano, 2008; Seefeldt and Cassano, 2012). For 2009 and

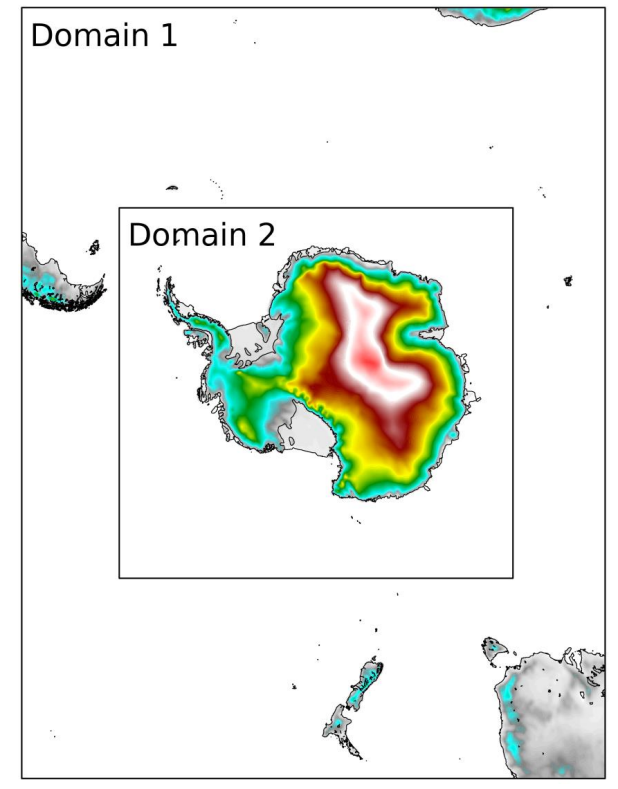

Figure 2. AMPS domains used for model output analysis in this study.

2010, the WRF output over the Dome C region reflects a forecast domain with a horizontal grid spacing of $15 \mathrm{~km}$, employing 44 vertical levels between the surface and $10 \mathrm{hPa}$. This $15 \mathrm{~km}$ grid was nested within a $45 \mathrm{~km}$ grid covering the Southern Ocean, and Fig. 2 shows these domains.

Model output from AMPS has been verified through various means over the years. Multi-year AMPS forecast evaluations have been conducted (Bromwich et al., 2005), and WRF's ability for the Antarctic in particular has been confirmed (Bromwich et al., 2013). AMPS's and WRF's Antarctic performance has also been documented in a number of case and process studies (e.g. Nigro et al., 2011, 2012; Powers, 2007; Bromwich et al., 2013). For model development within AMPS, verification for both warm and cold season periods is performed prior to changes in model versions or configurations (Powers et al., 2012). The reliability of AMPS WRF forecasts is also reflected in their demand from international Antarctic operations and field campaign forecasting efforts (see e.g. Powers et al., 2012). Lastly, similarly to how it is used here, AMPS output has been a key tool in previous published studies of Antarctic precipitation related to ice core analyses (Schlosser et al., 2008, 2010a, b).

In this study the WRF output from the AMPS archive is used to study both the synoptic patterns/general atmospheric circulation and the local conditions related to the precipitation regimes and events in the years compared. The WRF forecasts provide reliable depictions of conditions and their evolution. 
(a)

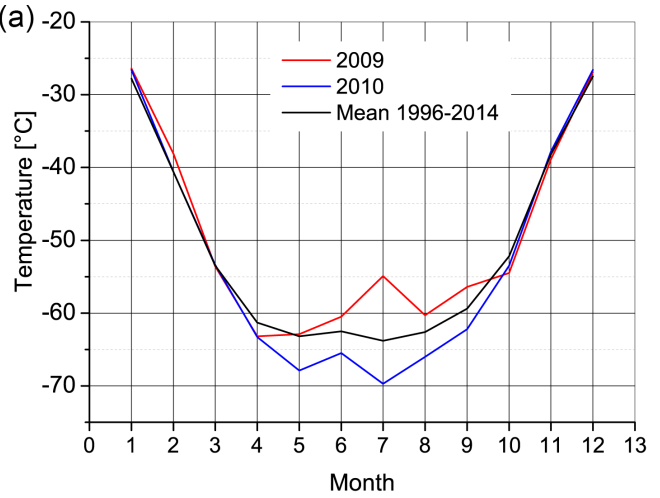

(b)

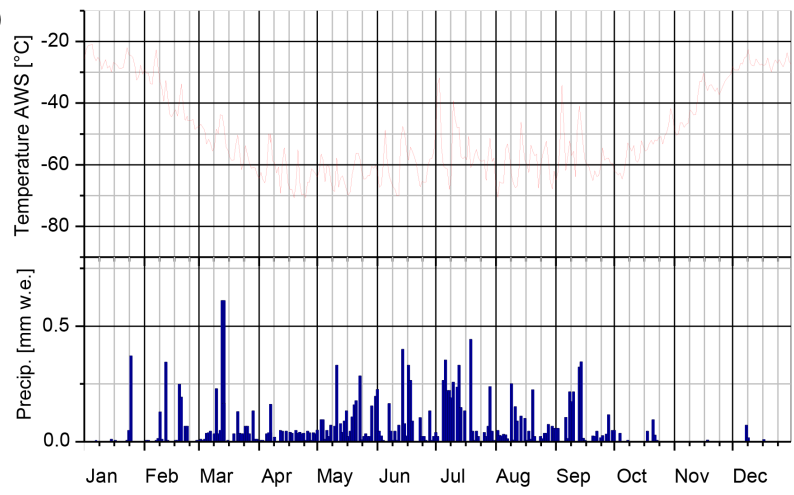

(c)

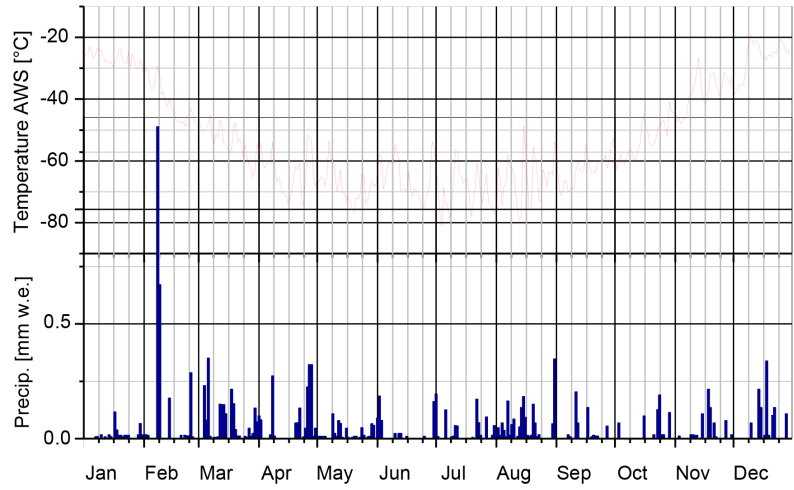

Figure 3. (a) Mean monthly temperatures for 2009 and 2010 at Dome C AWS. (b) Daily precipitation and daily mean temperature at Dome C for 2009 and 2010.

\section{Results}

\subsection{Temperature and precipitation}

Figure 3a shows the mean monthly air temperature observed at the Dome C AWS for 2009 and 2010 as well as the mean of 1996-2014. The mean annual cycle exhibits the typical coreless winter (van Loon, 1967) with a distinct temperature maximum in summer (December/January), which has no counterpart in winter, where the months May to August show relatively similar values. This is due to a combination of the local surface radiation balance and warm air intrusions. During the first part of the polar night, with the lack of shortwave radiation, an equilibrium of downwelling and upwelling longwave radiation is reached; advection of relatively warm air from lower latitudes further reduces the possibility for cooling. Thus the temperature does not decrease significantly after May (Schwerdtfeger, 1984; King and Turner, 1997).

While during the summer months little difference is seen between 2009 and 2010, the winter months are strikingly different. The lowest mean July temperature of the station record occurs in 2010 with a value of $-69.7^{\circ} \mathrm{C}$. This is the lowest monthly mean ever observed at Dome C, $5.9^{\circ} \mathrm{C}$ lower than the average 1996-2014, corresponding to a deviation of $1.7 \sigma, \sigma$ being the standard deviation. In contrast, the high- est July mean temperature is found in 2009; with a value of $-54.9^{\circ} \mathrm{C}$, it was $8.9^{\circ} \mathrm{C}$ higher (corresponding to $2.5 \sigma$ ) than the long-term July mean and the only July mean that exceeded $-60^{\circ}$ C. In Fig. 3b, observed daily mean temperatures and daily precipitation sums for the years 2009 and 2010 are displayed. Again, the differences between the 2 years are most striking in winter. In 2009, the temperature variability is very high, and several warming events with temperatures up to almost $-30^{\circ} \mathrm{C}$ can be seen. Minimum temperatures are rarely lower than $-70^{\circ} \mathrm{C}$ whereas in 2010 , minima are close to $-80^{\circ} \mathrm{C}$. The highest temperature in the winter of 2010 was only slightly above $-50^{\circ} \mathrm{C}$. The winter 2009 thus was not only a "coreless winter", but had a "warm" core due to the high number of warm air intrusions.

A very high precipitation value of $1.36 \mathrm{~mm}$ was measured on 9 February 2010, followed by $0.67 \mathrm{~mm}$ on 10 February, both classified as diamond dust from the photographic crystal analysis. Considering the extremely low density of diamond dust, a diamond dust amount of more than $1 \mathrm{~mm} \mathrm{day}^{-1}$ at first seemed to be unlikely. However, the model data do show a precipitation event connected to warm air advection from the north (see below) for this day, which would indicate the occurrence of snowfall rather than diamond dust. Most likely a mixture of crystal types was found during this event with the diamond dust on top of the snow crystals, which possibly led to the classification of the event as diamond dust. (Note that 


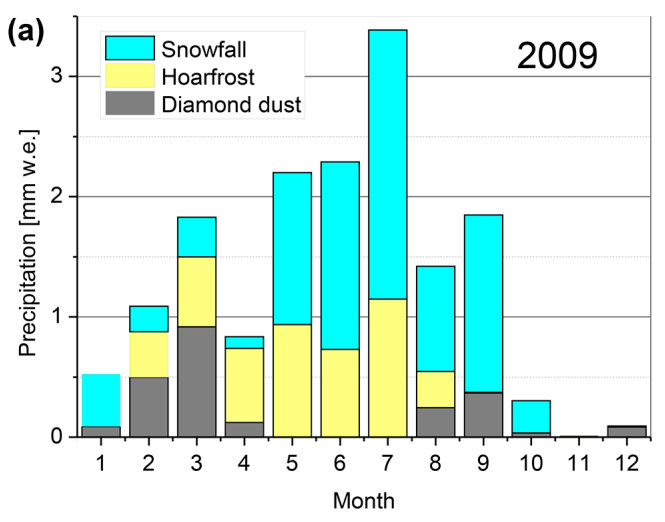

(c)

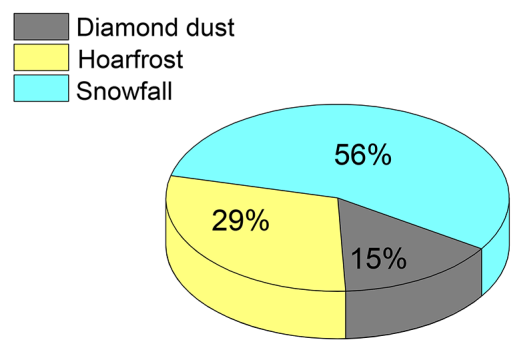

(b)

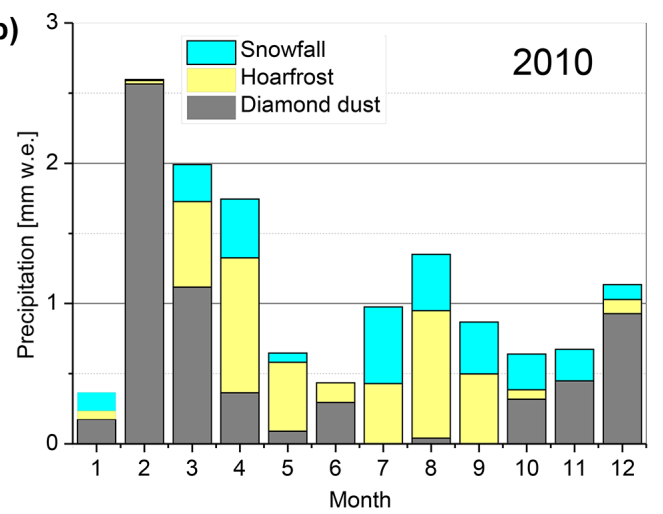

(d)

2009

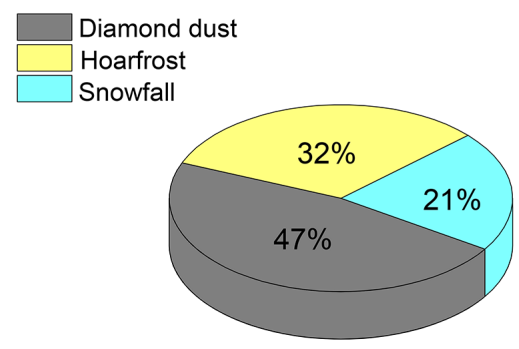

Figure 4. Monthly precipitation at Dome C (a) 2009 and (b) 2010, distinguishing three different types of precipitation: diamond dust, hoar frost, and snowfall. Relative frequency of diamond dust, hoar frost, and snowfall for (c) 2009 and (d) 2010. The types were determined from photos of the crystals on the platforms by the Avalanche Research Institute, Arabba, Italy.

the crystal classification was carried out purely from photographs by an expert at the Avalanche Institute in Italy and that snow crystals are also comparatively small at the temperatures prevailing at Dome C). Also, it was found that increased amounts of diamond dust can prevail after snowfall events when humidity is still increased compared to the average, but not large enough to cause real snowfall. The precipitation totals for May to September are 12.0 for 2009 and $4.3 \mathrm{~mm}$ w.e. for 2010 . Daily sums exceed $0.25 \mathrm{~mm}$ only three times in 2010, but 16 times in 2009. Usually, high daily precipitation amounts are associated with relative maxima in air temperature. In general, the winter of 2010 was cold and dry, whereas 2009 was relatively warm and moist compared to the long-term average.

Figure 4a shows monthly precipitation amounts for 2009 and 2010, distinguishing between diamond dust, hoar frost, and snowfall; Fig. $4 \mathrm{~b}$ gives the relative frequencies of the three different observed types of precipitation for both years. Again, large differences between 2009 and 2010 are found. While approximately half of the precipitation fell as snow in 2009 , less than a quarter of the total precipitation stemmed from snowfall in 2010, when mostly diamond dust was observed. As seen before, the winter months of May to September exhibit the largest differences. In particular, the extremely "warm" July of 2009 brought high amounts of snowfall. The lowest amounts of precipitation are seen in austral summer
2009/2010, with no precipitation observed in November and only very small amounts in December and January.

The total amount of precipitation measured on the raised platform is 16.5 for 2009 and $13.4 \mathrm{~mm}$ w.e. for 2010, compared to the mean annual accumulation of $25 \mathrm{~mm}$ w.e. derived from firn core and stake measurements (Frezzotti et al., 2005). From the available data it cannot be determined whether the difference is due to snow removed from the measuring platform by wind or sublimation or snow added to the snow surface at the stake array by wind (blowing or drifting snow) or deposition (re-sublimation).

\subsection{Atmospheric flow conditions}

\subsubsection{Synoptic analyses with AMPS archive data}

The synoptic situations that caused precipitation at Dome $\mathrm{C}$ were analysed using WRF output data from the AMPS archive. In particular, fields of $500 \mathrm{hpa}$ geopotential height and $24 \mathrm{~h}$ precipitation were used. For the $500 \mathrm{hPa}$ geopotential height information the $12 \mathrm{~h}$ forecast was utilized. For $24 \mathrm{~h}$ precipitation, the $12-36 \mathrm{~h}$ forecast sums of precipitation (rather than 0-24h) were used to allow for model spin up of clouds and microphysical fields. This is considered long enough for moist process spin-up, but avoids error growth reflected in longer forecast times (Bromwich et al., 2005). 


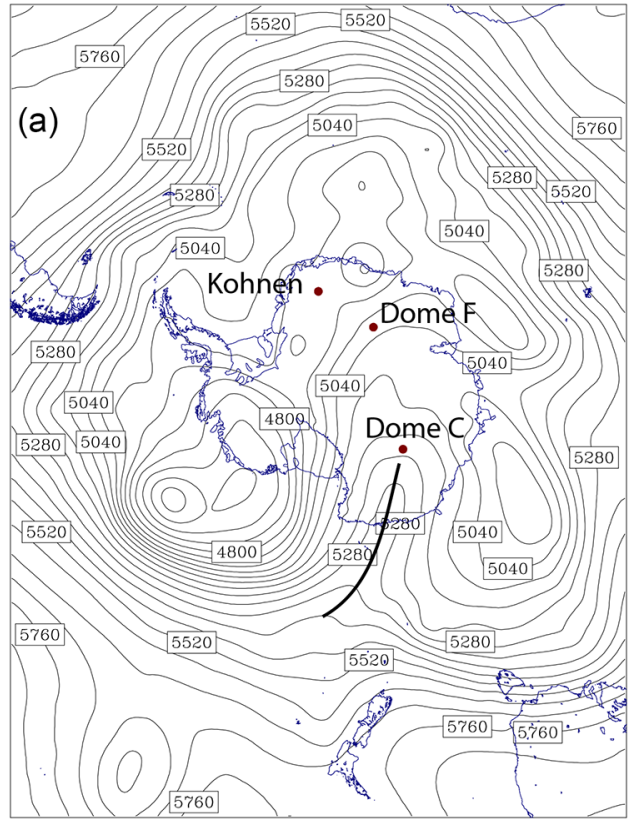

(b)

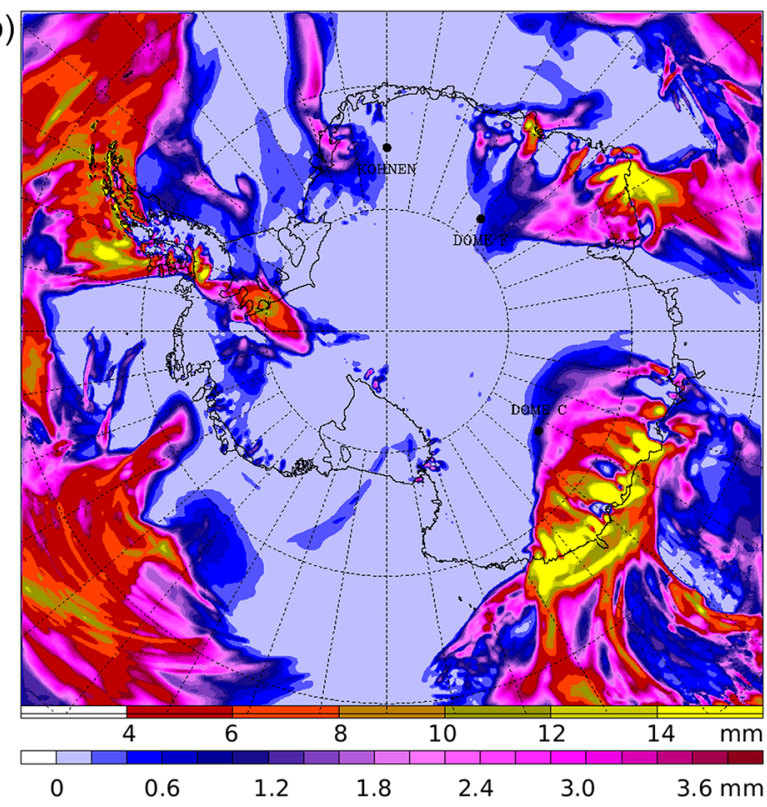

Figure 5. (a) $500 \mathrm{hPa}$ geopotential height from AMPS archive data (Domain 1) 13 September 2009 00:00 GMT. The axis of the upper-level ridge mentioned in the text is marked by a bold black line. (b) 24 h precipitation from AMPS 13 September 2009 00:00 to 24:00 GMT.

For all precipitation events with observed daily sums exceeding $0.2 \mathrm{~mm}$, the synoptic situations that caused the precipitation were investigated. In total, 29 events were studied, 20 in 2009 and 9 in 2010. For 2009 (2010), the model showed precipitation at Dome C in $44 \%$ (50\%) of the studied cases and precipitation in the vicinity in 33 (25) \% of the cases; no precipitation was shown in the model in $22(25) \%$ of the cases. In total, approximately half of the precipitation events were represented well by the model, one quarter showed synoptic events that did not bring precipitation exactly at the location and time of the measurements, and one quarter of the cases were not forecast by the model at all. An exact quantitative analysis of the model skill using the entire data series starting in 2006 is ongoing and the results will be more meaningful than those of only two, not very typical, years.

Generally, snowfall events were found to be associated with an amplification of the Rossby waves in the circumpolar westerlies, which causes a northerly flow across the Dome $\mathrm{C}$ region between a trough to the west and an upper-level ridge to the east of Dome $\mathrm{C}$. This northerly flow brings relatively warm and moist air from as far as $35-40^{\circ} \mathrm{S}$ to the East Antarctic plateau, leading to orographic precipitation when it is forced to ascend on the way from the coast to the highaltitude interior. Variations of this general situation are due to the duration of the flow pattern (e.g. whether there is a blocking anticyclone or not) and the strength of the upperlevel ridge, which determines how far north the main moisture origin is situated. Figure 5 shows an example of this synoptic situation typical for snowfall events. In the $500 \mathrm{hPa}$ geopotential height field (Fig. 5a) for 13 September 2009 the amplified ridge that leads to a northerly flow towards Dome $\mathrm{C}$ can be seen slightly east of Dome $\mathrm{C}$, with an axis tilted in a NE-SW direction. Figure $5 \mathrm{~b}$ displays the $24 \mathrm{~h}$ precipitation caused by the N-NE flow onto the continent. Dome C is situated at the southeastern edge of the precipitation area.

A frequent occurrence of the synoptic situation described (as it was the case in 2009) means a more northern mean moisture source than on average, which has to be taken into account for deriving air temperature from stable isotopes. (A detailed study using trajectory calculations for all observed precipitation events at Dome $\mathrm{C}$ is ongoing). It was also found to be typical for precipitation events at Dome $\mathrm{C}$ that the main westerly flow is split into a northern branch that remains zonal, whereas the southern branch starts meandering with a strong meridional component. This is observed more often at Dome C than at Dome F (Dittmann et al., 2016) or at Kohnen Station (Schlosser et al., 2010a).

Figure 6 presents an example for a case with no precipitation in the model, but relatively large observed precipitation amounts. The $500 \mathrm{hPa}$ geopotential height field (Fig. 6a) shows a cutoff high west of Dome $\mathrm{C}$ on the day after the precipitation event shown in Fig. 5. The remaining atmospheric moisture is not sufficient to produce precipitation in the model (Fig. 6b), but it does lead to remarkably high amounts of diamond dust and/or hoar frost $(0.7 \mathrm{~mm}$ observed during this event). This synoptic situation was also found by Hirasawa et al. (2013) in a detailed study of the synoptic conditions and precipitation during and after a blocking event at Dome Fuji. (Note that neither diamond dust nor hoar frost formation is specifically parameterized in the model). 


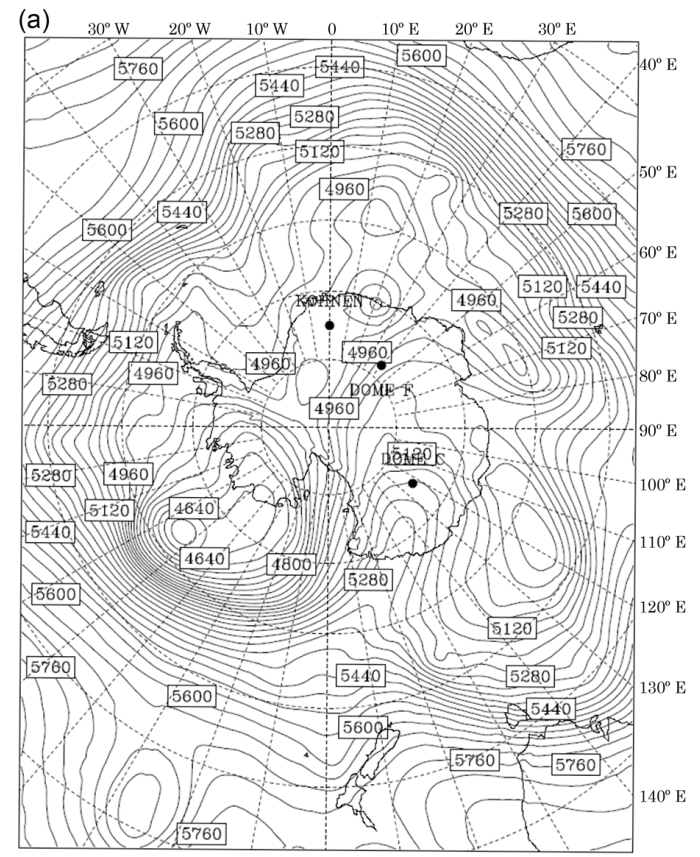

(b)

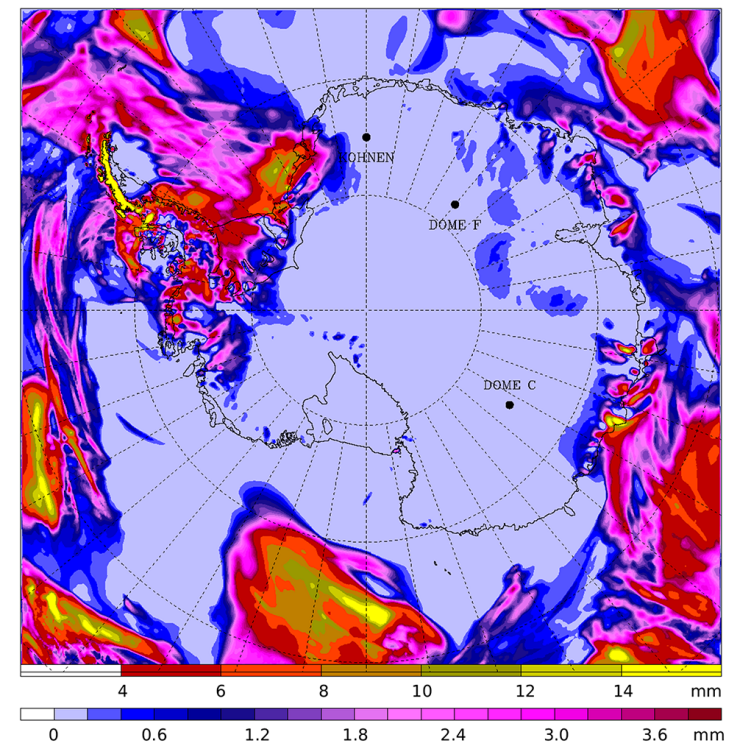

Figure 6. Example for synoptic situation, during which precipitation is observed at Dome C, but not forecast by WRF in AMPS. (a) $500 \mathrm{hPa}$ geopotential height, Domain 2. (b) $24 \mathrm{~h}$ precipitation total $(\mathrm{mm})$ from AMPS.

In 2010 , the flow was mainly zonal and the synoptic situations described above were much less frequent than in 2009 and not as strongly developed.

Using the WRF output, monthly mean fields of $500 \mathrm{hPa}$ geopotential height were calculated to compare the general flow conditions in 2009 and 2010. Figure 7 shows the composite mean $500 \mathrm{hPa}$ geopotential height for July 2009 and 2010, respectively. Even in the monthly mean, the distinct upper-level ridge in 2009 that projects onto the East Antarctic plateau and leads to warm air advection and increased precipitation at Dome $\mathrm{C}$ is clearly seen.

In 2010, in the monthly average, the flow was mainly zonal, which reduced the meridional exchange of heat and moisture, thus leading to lower temperatures and less precipitation in the interior of the Antarctic continent.

\subsubsection{Southern Annular Mode}

The occurrence of high-precipitation events on the Antarctic plateau due to amplification of Rossby waves is often connected to a strongly negative phase of the Southern Annular Mode (SAM). The SAM is the dominant mode of atmospheric variability in the extratropical Southern Hemisphere. It is revealed as the leading empirical orthogonal function in many atmospheric fields (e.g. Thompson and Wallace, 2000), such as surface pressure, geopotential height, surface temperature, and zonal wind (Marshall, 2003). Since pressure fields from global reanalyses commonly used to study the SAM are known to have relatively large errors in the polar regions, Marshall (2003) defined a SAM index based on surface ob- servations. He calculated the pressure differences between 40 and $65^{\circ} \mathrm{S}$ using data from six mid-latitude stations and six Antarctic coastal stations to calculate the corresponding zonal means. A large (small) meridional pressure gradient corresponds to a positive (negative) SAM index. The positive index means strong, mostly zonal westerlies and comparatively little exchange of moisture and energy between middle and high latitudes, which leads to a general cooling of Antarctica, except for the Antarctic Peninsula that projects into the westerlies. A negative SAM index is associated with weaker westerlies and a larger meridional flow component.

Figure 8 shows the monthly mean SAM index for 2009 and 2010. Whereas in the winter months (May to September) of 2009 the SAM index was generally negative (with the exception of a weakly positive value in June), 2010 has positive indices from April to August, with strongly positive values in June and July, and only a weakly negative index in September. This is consistent with the pattern of a strong zonal flow with few precipitation events at Dome C due to amplified ridges in the winter of 2010, with the opposite situation holding in 2009. The highest SAM index is found in November 2010; however, in austral summer the relationship between the SAM index and precipitation seems to be less straightforward. The differences between 2009 and 2010 are not extraordinarily high compared to other years (e.g. 2001/2002 as seen at http://www.nerc-bas.ac.uk/public/ icd/gjma/newsam.spr.pdf), however, qualitatively they are in agreement with the observed flow pattern. Furthermore, it should be kept in mind that SAM explains only about one 
(a)

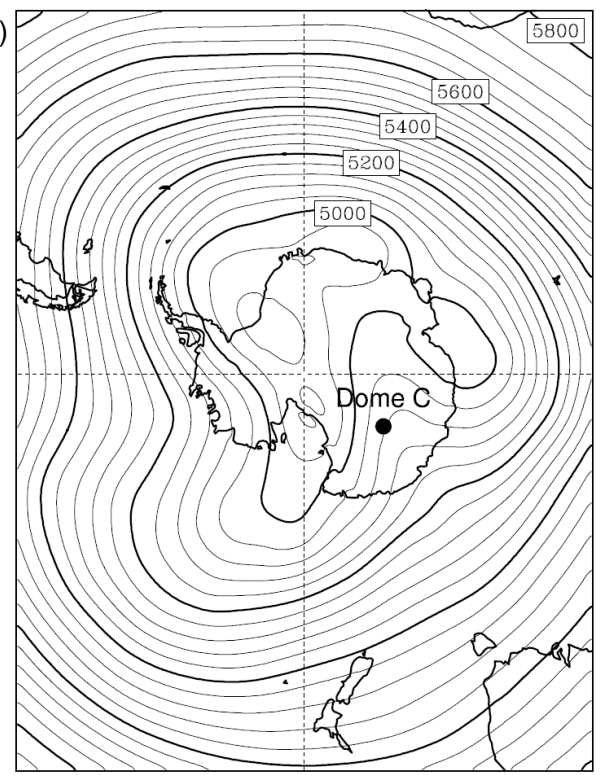

(b)

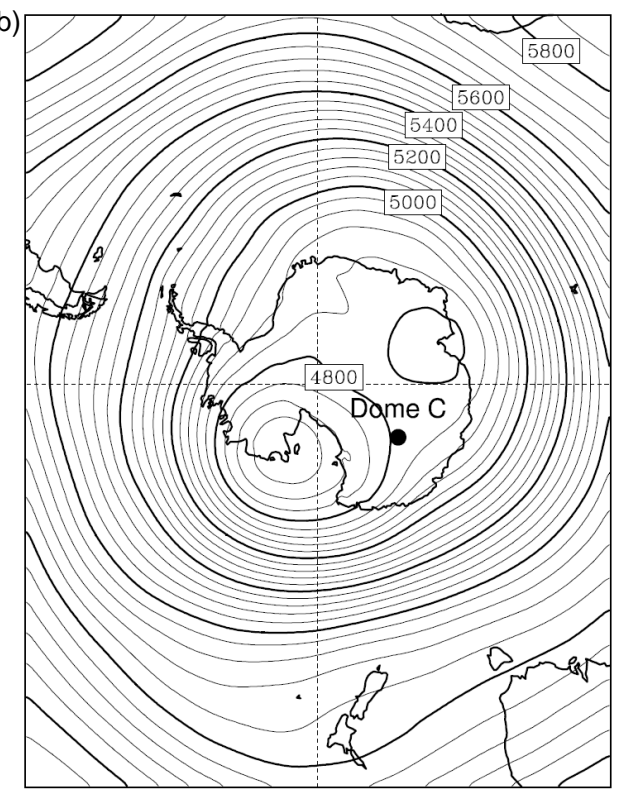

Figure 7. Mean July - $500 \mathrm{hPa}$ geopotential height based on AMPS archive model output for 2009 and 2010.

third of the atmospheric variability in the Southern Hemisphere (Marshall, 2007) and that the SAM index alone gives no information about the location of respective ridges and troughs in a highly meridional flow pattern.

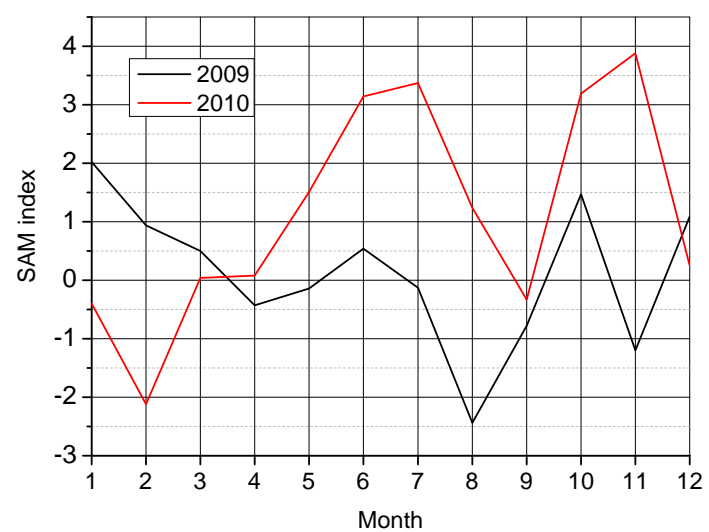

Figure 8. Mean monthly SAM index for 2009 and 2010 (after Marshall, 2003).

\subsubsection{Zonal wave number 3}

Another method to investigate the general atmospheric flow conditions is to analyse spatial and temporal variations of the quasi-stationary zonal waves in the Southern Hemisphere. In this study zonal wave number 3 (ZW3) is used. While the atmospheric circulation in the Southern Hemisphere appears strongly zonal (or symmetric), there is a significant nonzonal (asymmetric) component and ZW3 represents a significant proportion of this asymmetry. It is a dominant feature of the circulation on a number of different time scales (e.g. Karoly, 1989), it is responsible for $8 \%$ of the spatial variance in the field (van Loon and Jenne, 1972), and contributes significantly to monthly and interannual circulation variability (e.g. Trenberth and Mo, 1985). The asymmetry is revealed when the zonal mean is subtracted from the geopotential height field thereby creating a coherent pattern of zonal anomalies, with the flow associated with these patterns becoming apparent. ZW3 has preferred regions of meridional flow, which influence the meridional transport of heat and moisture into and out of the Antarctic. Raphael (2004) defined an index of ZW3 based on its amplitude (effectively the size of the zonal anomaly) at $50^{\circ} \mathrm{S}$ showing that $\mathrm{ZW} 3$ has identifiable positive and negative phases associated with the meridionality of the flow. A positive value for this index indicates more meridional flow (large zonal anomaly) and a negative value more zonal flow (small zonal anomaly). Note that the ZW3 index used here does not fully capture the shift in phase of the wave. However, Raphael (2004) found that the net effect is a small reduction in the amplitude of the wave, but the sign of the index is not influenced. A new approach for identifying Southern Hemisphere quasi-stationary planetary wave activity that allows variations of both wave phase and amplitude is described in a recent study by Irving and Simmonds (2015).

Figure 9a shows the monthly mean ZW3 index for the period 2009-2010. From June to September 2009 the ZW3 index was largely positive except for a comparatively small 
(a)

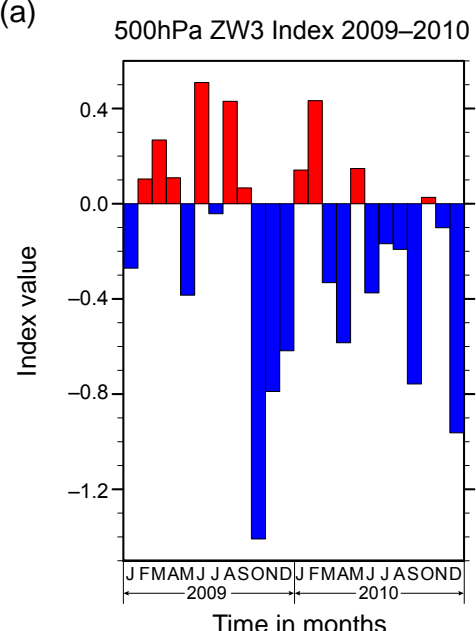

(b)

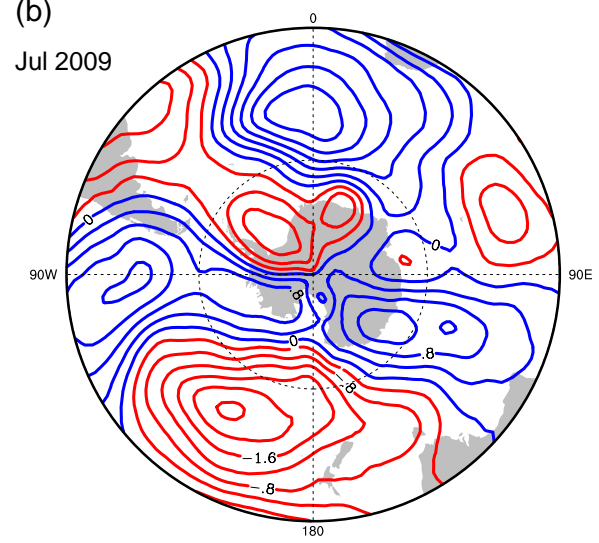

(c)

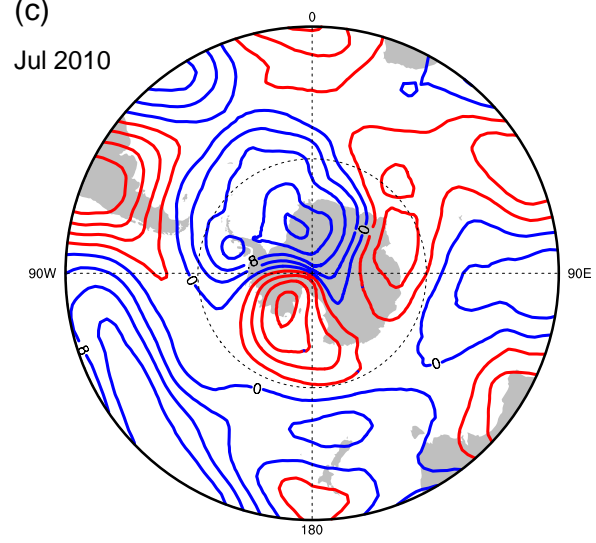

Figure 9. (a) Monthly mean zonal wave number 3 (ZW3) index for 2009-2010. (b) July $2009500 \mathrm{hPa}$ geopotential height anomaly: mean July 2009 height minus long-term zonal mean height. (c) July 2010500 hPa geopotential height anomaly: mean July 2009 height minus long-term zonal mean height.

negative excursion in July. On the contrary, from June to September 2010 it was negative. The asymmetry in the circulation suggested by the index is shown in Fig. 9b and c (July 2009 and July 2010). These figures were created by subtracting the long-term zonal mean at each latitude, from the mean
$500 \mathrm{hPa}$ geopotential height field in July 2009 and 2010, respectively. The flow onto Dome $\mathrm{C}$ suggested by the alternating negative and positive anomalies is northerly in July 2009, but has a strong zonal component in July 2010. This information given by the ZW3 index and the patterns of zonal anomalies is consistent with that suggested by the SAM.

\section{Discussion and conclusion}

In the present study that was motivated by stable water isotope studies, atmospheric conditions of the two contrasting years 2009 and 2010 at the Antarctic deep-drilling site Dome C, on the East Antarctic Plateau were investigated using observational precipitation and temperature data and data from a mesoscale atmospheric model. The observations from Dome $\mathrm{C}$ represent the first and only multi-year series of daily precipitation/stable isotope measurements at a deep-drilling site, even though "multi" means only 9 years in this case. The differences between the 2 years 2009 and 2010 were most striking in winter. Whereas 2009 was relatively warm and moist due to frequent warm air intrusions connected to amplification of Rossby waves in the circumpolar westerlies, the winter of 2010 was extremely cold and dry, with the lowest monthly mean July temperature observed since the beginning of the AWS measurements in 1996. This can be explained by the prevailing strong zonal flow in the winter of 2010, related to a strongly positive SAM index and a negative ZW3 index. Also, the frequency distribution of the various precipitation types was largely different in 2009 and 2010, with snowfall prevailing in 2009 whereas diamond dust was dominant in 2010.

Similarly striking differences in weather conditions of 2009 and 2010 were seen in other parts of East Antarctica. Gorodetskaya et al. (2013) found that accumulation in 2009 was eight times higher than in 2010 at the Belgian yearround station "Princess Elisabeth". At this location, the temperature was also higher in 2009 than in 2010, particularly in autumn and early winter. The findings are supported by Boening et al. (2012), who used observations from GRACE (Gravity Recovery And Climate Experiment) and found an abrupt mass increase on the East Antarctic ice sheet in the period 2009-2011. Similarly, Lenaerts et al. (2013) investigated snowfall anomalies in Dronning Maud Land, East Antarctica. They stated that the large positive anomalies of accumulation found in 2009 and 2011 stand out in the past approximately 60 years although comparable anomalies are found further back in time.

Distinguishing between the different forms of precipitation, namely diamond dust, hoar frost and dynamically caused snowfall, is important for both mass balance and ice core interpretation. For mass balance, the different precipitation types do not have to be known if the surface mass balance is determined as an annual value from snow pits, firn and/or ice cores or stake arrays. For temporally higher 
resolved precipitation measurements, however, a fraction of both hoar frost and diamond dust might be just a part of the local cycle of sublimation and deposition (re-sublimation), thus representing no total mass gain. More detailed measurements are thus necessary to allow a better understanding of the processes involved. This also applies to isotopic fractionation during this cycle; continuous measurements of water vapour stable isotope ratios (e.g. Steen-Larsen et al., 2013) should be included here.

For ice core interpretation, the problem generally becomes more complex. Diamond dust is observed during the entire year without a distinct seasonality. Therefore a signal from an ice core property measured in the ice (in contrast to measured in the air bubbles) will have contributions from diamond dust that stem nearly equally from all seasons. Although snowfall events are not very frequent at deep ice core drilling sites, they can account for a large percentage of the total annual precipitation (accumulation) at those locations. If these events have a seasonality that has changed between glacials and interglacials, a large bias will be found in the temperature derived from the stable isotopes in ice cores. Today, the frequency of such snowfall events shows a high inter-annual variability, but both frequency and seasonality of the events might be different in a different climate due to changes in the general atmospheric circulation and in sea ice extent (e.g. Godfred-Spenning and Simmonds, 1996). Since it was found that snowfall events are connected to the synoptic activity in the circumpolar trough, it is plausible that the seasonality of such events was different during glacial times because the sea ice edge and the mean position of the westerlies were considerably farther north than today. This influences the zone of the largest meridional temperature gradient, thus the largest baroclinicity and consequently cyclogenesis. A larger sea ice extent might reduce the number of snowfall events in the Antarctic interior in winter by pushing the zone of largest baroclinicity northwards. However, it is not possible to assess such hypotheses using observational data since the instrumental period, with few exceptions, started in Antarctica not before the IGY (International Geophysical Year) 1957/58. However, modelling studies can be supported by studies of the physical processes in the atmosphere using recent data, and, in particular, cases of extreme situations can be helpful here. Even if the full amplitude of the change between glacial and interglacial climates is not observed, extrema can give insight into the sign and kind of the reaction of the system to a change in one or several atmospheric variables.

Another implication for ice core interpretation derived from the present study is that a more northern moisture source does not necessarily mean larger isotopic fractionation (which is usually assumed in ice core studies (e.g. Stenni et al., 2001, 2010). Even without a quantitative determination of the moisture source it can be said that in an increased meridional flow, as in 2009, heat and moisture transport from relatively low latitudes is increased, too, and leads to higher precipitation stemming from more northern oceanic sources than on average. Although the temperature at the main moisture source is higher than on average for a more northern moisture source, the depletion in heavy isotopes is comparatively small because the temperature at the deposition site is also clearly higher than on average due to the warm air advection, which reduces the temperature difference between the moisture source region and the deposition site, thus the amount of isotopic fractionation.

Looking towards future work, the results here indicate that a combination of process studies using recent data and modelling of the atmospheric flow conditions on larger timescales will lead to a better quantitative interpretation of ice core data. Apart from the factors influencing precipitation itself, it has become clear recently that post-depositional processes between snowfall events are more important than previously thought because, additionally to processes within the snowpack, the interaction between the uppermost parts of the snowpack and the atmosphere is very intense (Steen-Larsen et al., 2013). Parallel measurements of stable isotope ratios of water vapour and surface snow, combined with meteorological data will give more insight into these processes in Antarctica.

Altogether, this means that, compared to years with predominantly zonal flow (which is the more frequent situation), in years with enhanced meridional flow (negative SAM index, positive ZW3 index) higher temperatures and higher amounts of precipitation that is less depleted of heavy isotopes are expected at Dome $\mathrm{C}$ and comparable interior sites in Antarctica. This is particularly valid for the colder seasons.

The relationship between air temperature and stable isotopes of Antarctic precipitation and/or ice is anything else but straightforward, since the isotope ratio measured in an ice core (or in the snow) is the result of a complex precipitation history that is strongly influenced by the synoptics and general atmospheric flow conditions, followed by post-depositional processes. Without thorough knowledge of all the processes involved a quantitatively correct derivation of palaeotemperatures from ice core stable water isotopes is thus not possible.

Author contributions. B. Stenni is responsible for the precipitation measurements, M. Valt and A. Cagnati for the crystal analysis. M. Raphael did the ZW3 study. M. G. Duda and K. W. Manning assisted with software development. E. Schlosser prepared the manuscript with contributions from J. G. Powers, K. W. Manning, M. Raphael, and B. Stenni.

Acknowledgements. The precipitation measurements at Dome C have been conducted in the framework of the Concordia station glaciology and ESF PolarCLIMATE HOLOCLIP projects funded in Italy by PNRA-MIUR. This is a HOLOCIP publication no. 27. The present study is financed by the Austrian Science Funds (FWF) under grant P24223. AMPS is supported by the US National 
Science Foundation, Division of Polar Programs. We appreciate the support of the University of Wisconsin-Madison Automatic Weather Station Program with the Dome C II data set. (NSF grant nos. ANT-0944018 and ANT-12456663). We thank Gareth Marshall for providing the SAM indices online. We thank all winterers at Dome $\mathrm{C}$, who did the precipitation sampling. We also thank our editor, Heini Wernli, and Harald Sodemann and two anonymous reviewers for helpful comments that improved the manuscript.

Edited by: H. Wernli

\section{References}

Birnbaum, G., Brauner, R., and Ries, H.: Synoptic situations causing high precipitation rates on the Antarctic plateau: observations from Kohnen Station, Dronning Maud Land, Antarct. Sci., 18, 279-288, doi:10.1017/S0954102006000320, 2006.

Boening, C., Lebsock, M., Landerer, F., and Stephens, G.: Snowfalldriven mass change on the East Antarctic ice sheet, Geophys. Res. Lett., 39, L21501, doi:10.1029/2012GL053316, 2012.

Braaten, D. A.: Direct measurements of episodic snow accumulation on the Antarctic polar plateau, J. Geophys. Res., 105, 10119-1128, 2000.

Bromwich, D. H: Snowfall in high southern latitudes, Rev. Geophys., 26, 149-168, 1988.

Bromwich, D. H., Guo, Z., Bai, L., and Chen, Q. : Modeled Antarctic Precipitation, Part I: Spatial and Temporal Variability, J. Climate, 17, 427-447, 2004.

Bromwich, D. H., Monaghan, A. J., Manning, K. W., and Powers, J. G.: Real-time forecasting for the Antarctic: An evaluation of the Antarctic Mesoscale Prediction System (AMPS), Mon. Weather Rev., 133, 579-603, 2005.

Bromwich, D. H., Otieno, F. O., Hines, K. M., Manning, K. W., and Shilo, E.: Comprehensive evaluation of polar weather research and forecasting performance in the Antarctic, J. Geophys. Res., 118, 274-292, doi:10.1029/2012JD018139, 2013.

Church, J. A., Clark, P. U., Cazenave, A., Gregory, J. M., Jevrejeva, S., Levermann, A., Merrifield, M. A., Milne, G. A., Nerem, R. S., Nunn, P. D., Payne, A. J., Pfeffer, W. T., Stammer, D., and Unnikrishnan, A. S.: Sea Level Change, in: Climate Change 2013: The Physical Science Basis, Contribution of Working Group I to the Fifth Assessment Report of the Intergovernmental Panel on Climate Change, edited by: Stocker, T. F., Qin, D., Plattner, G. K., Tignor, M., Allen, S. K., Boschung, J., Nauels, A., Xia, Y., Bex, V., and Midgley, P. M., Cambridge University Press, Cambridge, United Kingdom and New York, NY, USA, 2013.

Dansgaard, W.: Stable isotopes in precipitation, Tellus, XVI, 436468, 1964

Dittmann, A., Schlosser, E., Masson-Delmotte, V., Powers, J. G., Manning, K. W., Werner, M., and Fujita, K.: Precipitation regime and stable isotopes at Dome Fuji, East Antarctica, Atmos. Chem. Phys. Discuss., doi:10.5194/acp-2015-1012, in review, 2016.

Enomoto, H., Motoyama, H., Shiraiwa, T., Saito, T., Kameda, T., Furukawa, T., Takahashi, S., Kodama, Y., and Watanabe, O.: Winter warming over Dome Fuji, East Antarctica and semiannual oscillation in the atmospheric circulation, J. Geophys. Res., 103, 23103-23111, 1998.
EPICA community members: 8 Glacial cycles from an Antarctic ice core, Nature, 429, 623-628, doi:10.1038/nature02599, 2004.

Fogt, R. L.: Antarctica - overview, Chapter 6a, in: State of the Climate in 2009, 6. Antarctica, edited by: Arndt, D. S., Baringer, M. O., and M. R. Johnson, Special supplement to B. Am. Meteorol. Soc., 91, 125-134, 2010.

Fogt, R. L.: Antarctica - overview, Chapter 6a, in: State of the Climate in 2010, 6. Antarctica, edited by: Blunden, J., Arndt, D. S., and Baringer, M. O., Special supplement to B. Am. Meteorol. Soc., 92, 161-172, 2011.

Frezzotti, M., Pourchet, M., Onelio, F., Gandolfi, S., Gay, M., Urbini, S., Vincent, C., Becagli, S., Gragnani, R., Proposito, M., Severi, M., Traversi, R., Udisti, R., and Fily, M.: Spatial and temporal variability of snow accumulation in East Antarctica from traverse data, J. Glaciol., 51, 113-123, 2005.

Frieler, K., Clark, P. U., He, F., Buizert, C., Reese, R., Ligtenberg, S.R. M., Van den Broeke, M. R., Winkelmann, R., and Levermann, A.: Consistent evidence of increasing Antarctic accumulation with warming, Nature Climate Change, 5, 348-352, doi:10.1038/NCLIMATE2574, 2015.

Fujita, K. and Abe, O.: Stable isotopes in daily precipitation at Dome Fuji, East Antarctica, Geophys. Res. Lett., 33, L18503, doi:10.1029/2006GL026936, 2006.

Godfred-Spenning, C. and Simmonds, I.: An analysis of Antarctic Sea-Ice and Extratropical cyclone associations, Int. J. Climatol., 16, 1315-1332, 1996.

Gorodetskaya, I. V., Van Lipzig, N. P. M., Van den Broeke, M. R., Mangold, A., Boot, W., and Reijmer. C. H.: Meteorological regimes and accumulation patterns at Utsteinen, Dronning Maud Land, East Antarctica: Analysis of two contrasting years, J. Geophys. Res, 118, 1-16, doi:10.1002/jgrd.50177, 2013.

Harig, C. and Simons, F. J.: Accelerated West Antarctic ice mass loss continues to outpace East Antarctic gains, Earth Planet. Sc. Lett., 415, 134-141, 2015.

Hirasawa, N., Nakamura, H., and Yamanouchi, T.: Abrupt changes in meteorological conditions observed at an inland Antarctic station in association with wintertime blocking, Geophys. Res. Lett., 27, 1911-1914, 2000.

Hirasawa, N., Nakamura, H., Motoyama, H., Hayashi, M., and Yamanouchi, T.: The role of synoptic-scale features and advection in a prolonged warming and generation of different forms of precipitation at dome Fuji station, Antarctica, following a prominent blocking event, J. Geophys. Res., 118, 6916-6928, doi:10.1002/jgrd.50532, 2013.

Jouzel, J.: Treatise on Geochemistry, edited by: Holland, H. and Turekian, K., 2nd Edn., 5.8, Elsevier, 213-256, 2014.

Jouzel, J., Vimeux, F., Caillon, N., Delaygue, G., Hoffmann, G., Masson-Delmotte, V., and Parrenin, F.: Magnitude of isotope/temperature scaling for interpretation of central Antarctic ice cores, J. Geophys. Res., 108, 4361-4370, doi:10.1029/2002JD002677, 2003.

Karoly, D. J.: Southern Hemisphere circulation features associated with El Nino-Southern Oscillation events, J. Climate, 2, 12391251, 1989.

King, J. and Turner, J.: Antarctic Meteorology and Climatology. Cambridge Atmospheric and Space Sciences Series, Cambridge University Press, Cambridge, 409 pp., 1997.

Lenaerts, J. T. M., van Meijgaard, E., Van den Broeke, M.R., Ligtenberg, S. R. M., Horwarth, M., and Isaksson, E.: Recent snowfall 
anomalies in Dronning Maud Land, East Antarctica, in a historical and future climate perspective, Geophys. Res. Lett., 40, 2684-2688, doi:10.1002/grl.50559, 2013.

Lorius, C., Merlivat, L., Jouzel, J., and Pourchet, M.: A 30000 years isotope climatic record from Antarctic ice, Nature, 280, 644-647, 1979.

Marshall, G. J.: Trends in the Southern Annular Mode from observations and reanalyses, J. Climate, 16, 4134-4143, 2003.

Marshall, G. J.: Half-century seasonal relationship between the Southern Annular Mode and Antarctic temperatures, Int. J. Climatol., 27, 373-383, 2007.

Massom, R., Pook, M. J., Comiso, J. C., Adams, N., Turner, J., Lachlan-Cope, T., and Gibson, T.: Precipitation over the interior East Antarctic ice sheet related to midlatitude blocking-high activity, J. Climate, 17, 1914-1928, 2004.

Masson-Delmotte, V., Shugui, H., Ekaykin, A., Jouzel, J., Aristarain, A., Bernardo, R. T., Bromwich, D. H., Cattani, O., Delmotte, M., Falourd, S., Frezotti, M., Gallée, H., Genoni, L., Landais, A., Helsen, M., Hoffmann, G., Morgan, V., Motoyama, H., Noone, D., Oerter, H., Petit, J. R., Royer, A., Ruemura, R., Schmidt, G., Schlosser, E., Simoes, J., Steig, E., Stenni, B., Stievenard, M., Vimeux, F., and White, J. W. C.: A review of Antarctic surface snow isotopic composition: observations, atmospheric circulation and isotopic modelling, J. Climate, 21, 3359-3387, 2008.

Monaghan, A. J., Bromwich, D. H., Powers, J. G., and Manning, K. W.: The Climate of McMurdo, Antarctica, Region as Represented by One Year of Forecasts from the Antarctic Mesoscale Prediction System, J. Climate, 18, 1174-1189, 2005.

Monaghan, A. J., Bromwich, D. H., Fogt, R. L., Wang, S., Mayewski, P. A.,Dixon, D. A., Ekaykin, A., Frezzotti, M., Goodwin, I., Isaksson, E., Kaspari, S. D., Morgan, V. I., Oeter, H., Van Ommen, T. D., Van der Veen, C. J., and Wen, J.: Insignificant change in Antarctic snowfall since the International Geophysical Year, Science, 313, 827-831, doi:10.1126/science.1128243, 2006

Nicolas, J. P. and Bromwich, D. H.: Climate of West Antarctica and Influence of Marine Air Intrusions, J. Climate, 24, 49-67, doi:10.1175/2010JCLI3522.1, 2011

Nigro, M. A., Cassano, J. J., and Seefeldt, M. W.: A weather pattern-based approach to evaluate the Antarctic Mesoscale Prediction System (AMPS) forecasts: Comparison to automatic weather station observations, Weather Forecast., 26, 184-198, doi:10.1175/2010WAF2222444.1, 2011.

Nigro, M. A., Cassano, J. J., and Knuth, S. L.: Evaluation of Antarctic Mesoscale Prediction System (AMPS) cyclone forecasts using infrared satellite imagery, Antarct. Sci., 24, 183-192, doi:10.1017/S0954102011000745, 2012.

Noone, D. and Simmonds, I.: Implications for the interpretation of ice-core isotope data from analysis of modelled Antarctic precipitation, Ann. Glaciol., 27, 398-402, 1998.

Noone, D. and Simmonds, I.: Associations between $\delta^{18}$ O Of water and climate parameters in a simulation of atmospheric circulation for 1979-1995, J. Climate, 15, 3150-3169, 2002.

Noone, D., Turner, J., and Mulvaney, R.: Atmospheric signals and characteristics of accumulation in Dronning Maud Land, Antarctica, J. Geophys. Res., 104, 19191-19211, 1999.
Nygard, T., Valkonen, T., and Vihma, T.: Antarctic Low-Tropopause Humidity Inversions: 10-yr Climatology, J. Climate, 26, 52055219, doi:10.1175/JCLI-D-12-00446.1, 2013.

Powers, J. G., Monaghan, A. J, Cayette, A. M., Bromwich, D. H., Kuo, Y., and Manning, K. W.: Real-time mesoscale modeling over Antarctica. The Antarctic Mesoscale Prediction System, B. Am. Meteorol. Soc., 84, 1522-1545, 2003.

Powers, J. G.: Numerical prediction of an Antarctic severe wind event with the Weather Research and Forecasting (WRF) Model, Mon. Weather Rev., 135, 3134-3157, 2007.

Powers, J. G., Manning, K. W., Bromwich, D. H., Cassano, J. J., and Cayette, A. M.: A decade of Antarctic science support through AMPS, B. Am. Meteorol. Soc., 93, 1699-1712, 2012.

Raphael, M. N.: A zonal wave 3 index for the Southern Hemisphere, Geophys. Res. Lett., 31, L23212, doi:10.1029/2004GL020365, 2004.

Reijmer, C. H. and van den Broeke, M. R.: Temporal and spatial variability of the surface mass balance in Dronning Maud Land, Antarctica, J. Glaciol., 49, 512-520, 2003.

Reijmer, C. H., Van den Broeke, M. R., and Scheele, M. P.: Air parcel trajectories and snowfall related to five deep drilling locations in Antarctica based on the ERA-15 dataset, J. Climate, 15, 1957-1968, 2002.

Scarchilli, C., Frezzotti, M., and Ruti, P. M.: Snow precipitation at four ice core sites in East Antarctica - provenance, seasonality and blocking factors, Clim. Dynam., 37, 2107-2125, doi:10.1007/s00382-010-0946-4, 2010.

Schlosser, E.: Effects of seasonal variability of accumulation on yearly mean $\delta^{18} \mathrm{O}$ values in Antarctic snow, J. Glaciol., 45, 463468, 1999.

Schlosser, E., Duda, M. G., Powers, J. G, and Manning, K. W.: The precipitation regime of Dronning Maud Land, Antarctica, derived from AMPS (Antarctic Mesoscale Prediction System) Archive Data, J. Geophys. Res., 113, D24108, doi:10.1029/2008JD009968, 2008.

Schlosser, E., Manning, K. W., Powers, J. G., Duda, M. G., Birnbaum, G., and Fujita, K.: Characteristics of high-precipitation events in Dronning Maud Land, Antarctica, J. Geophys. Res., 115, D14107, doi:10.1029/2009JD013410, 2010a.

Schlosser, E., Powers, J. G., Duda, M. G., Manning, K. W., Reijmer, C. H., and Van den Broeke, M.: An extreme precipitation event in Dronning Maud Land, Antarctica - a case study using AMPS (Antarctic Mesoscale Prediction System) archive data, Polar Res., 1-15, doi:10.1111/j.1751-8369.2010.00164.x, 2010b.

Schlosser, E., Manning, K. W., Powers, J. G., Gillmeier, S., and Duda, M. G.: An extreme precipitation/warming event in Antarctica - a study with Polar WRF, in preparation, 2016.

Schwerdtfeger, W.: Weather and Climate of the Antarctic. Elsevier Science Publishers, Amsterdam-London-New York-Tokyo, 262 pp., 1984.

Seefeldt, M. W. and Cassano, J. J.: An analysis of low-level jets in the greater Ross Ice Shelf region based on numerical simulations, Mon. Weather Rev., 136, 4188-4205, doi:10.1175/2007JAMC1442.1, 2008.

Seefeldt, M. W. and Cassano, J. J.: A description of the Ross Ice Shelf air stream (RAS) through the use of selforganizing maps (SOMs), J. Geophys. Res., 117, D09112, doi:10.1029/2011JD016857, 2012. 
Simmonds, I., Keay, K., and Lim, E.: Synoptic activity in the seas around Antarctica, Mon. Weather Rev., 131, 272-288, 2002.

Sinclair, M. R.: Record-high temperatures in the Antarctic - A synoptic case study, Mon. Weather Rev., 109, 2234-2242, 1981.

Skamarock, W. C., Klemp, J. B., Dudhia, J., Gill, D. O., Barker, D. M., Duda, M. G., Huang, X., Wang, W, and Powers, J. G.: A description of the Advanced Research WRF Version 3, NCAR/TN 475+STR, 125 pp., Nat. Cent. for Atmos. Res., Boulder, Co, 2008.

Sodemann, H. and Stohl, A.: Asymmetries in the moisture origin of Antarctic precipitation, Geophys. Res. Lett., 36, L22803, doi:10.1029/2009GL040242, 2009.

Sodemann, H., Masson-Delmotte, V., Schwierz, C., Vinther, B. M., and Wernli, H.: Inter-annual variability of Greenland winter precipitation sources, Part II: Effects of North Atlantic Oscillation variability on stable isotopes in precipitation, J. Geophys. Res., 113, D12111, doi:10.1029/2007JD009416, 2008.

Stenni, B., Masson-Delmotte, V., Johnsen, S., Jouzel, J., Longinelli, A., Monnin, E., Roethlisberger, R., and Selmo, E.: An Oceanic Cold Reversal During the Last Deglaciation, Science, 293, 20742077, 2001.

Stenni, B., Masson-Delmotte, V., Selmo, E., Oerter, H., Meyer, H., Roethlisberger, R., Jouzel, J., Cattani, O., Falourd, S., Fischer, H., Hoffmann, G., Iacumin, P., Johnsen, S. F., Minster, B., and Udisti, R.: The deuterium excess records of EPICA Dome $\mathrm{C}$ and Dronning Maud Land ice cores (East Antarctica), Quaternary Sci. Rev., 29, 146-159, 2010.

Steen-Larsen, H. C., Johnsen, S. J., Masson-Delmotte, V., Stenni, B., Risi, C., Sodemann, H., Balslev-Clausen, D., Blunier, T., Dahl-Jensen, D., Ellehøj, M. D., Falourd, S., Grindsted, A., Gkinis, V., Jouzel, J., Popp, T., Sheldon, S., Simonsen, S. B., Sjolte, J., Steffensen, J. P., Sperlich, P., Sveinbjörnsdóttir, A. E., Vinther, B. M., and White, J. W. C.: Continuous monitoring of summer surface water vapor isotopic composition above the Greenland Ice Sheet, Atmos. Chem. Phys., 13, 4815-4828, doi:10.5194/acp-13-4815-2013, 2013.
Suzuki, K., Yamanouchi, T., and Motoyama, H.: Moisture transport to Syowa and Dome Fuji stations in Antarctica, J. Geophys. Res., 113, D24114, doi:10.1029/2008JD009794, 2008.

Thompson, D. W. J. and Wallace, J. M.: Annular modes in the extratropical circulation, Part I: Month-to-month variability, J. Climate, 13, 1000-1016, 2000.

Trenberth, K. E. and Mo, K. C.: Blocking in the Southern Hemisphere, Mon. Weather Rev., 133, 38-53, 1985.

Van Loon, H.: The half-yearly oscillation in middle and high southern latitudes and the coreless winter, J. Atmos. Sci., 24, 472-486, 1967.

Van Loon, H. and Jenne, R. L.: The zonal harmonic standing waves in the Southern Hemisphere, J. Geophys. Res., 77, 992-1003, 1972.

Winkelmann, R., Levermann, A., Martin, M. A., and Frieler, K.: Increased future ice discharge from Antarctica owing to higher snowfall, Nature, 492, 239-242, 2012. 